This is the post print version of the article, which has been published in Social Forces. 2018, 97 (1), 27-54. https://doi.org/10.1093/sf/soy028.

Retirement trajectories and income redistribution

\title{
Retirement trajectories and income redistribution through the pension system in Finland
}

Aart-Jan Riekhoff, University of Tampere

Noora Järnefelt, Finnish Centre for Pensions

\section{Acknowledgements}

Data for this paper were obtained from the Finnish Centre for Pensions with special permission. The authors would like to thank especially Tuula Kyyrä, Juha Knuuti and Janne Salonen for their help with the data and Kati Kuitto for her extensive comments on an earlier version of the manuscript.

Corresponding author: Aart-Jan Riekhoff, Faculty of Social Sciences, Kalevantie 5, 33014 University of Tampere, Finland. E-mail: arie.riekhoff@staff.uta.fi. 


\title{
Retirement trajectories and income redistribution through the pension system in Finland
}

\author{
Abstract \\ In this article, we investigate the redistributive outcomes of the Finnish pension system. We \\ hypothesize that a pension system does not straightforwardly diminish, maintain or increase income \\ differences after retirement, but it can have different outcomes for different groups. Our focus is on \\ differences in changes in income between groups that vary in their timing and type of retirement. \\ We make use of longitudinal register-based data from the Finnish Centre for Pensions and analyze \\ income and retirement trajectories of Finnish employees born in 1948 from the age of 57 to $66(N=$ \\ 44,449). Our aim is to find out in what way trajectories of income from earnings and pensions are \\ related to different types of retirement trajectories, while controlling for gender, sector of \\ employment, and length of working life. Eight distinct retirement trajectories are identified using \\ sequence analysis. The results of our multilevel regression models indicate that the pension system \\ sustains inequalities related to gender and employment sector. Early old-age retirement and part- \\ time retirement are associated with higher earnings and more generous pension entitlements, \\ indicating cumulative advantage. Lower earnings are associated with higher risk of early exit \\ through unemployment and disability pensions, while the pension system guarantees a minimum \\ income level in retirement, resulting in status levelling. Those who retire later are relatively well-off \\ in work, but worse-off in retirement, suggesting a status levelling outcome. By disentangling these \\ outcomes of the pension system, it is possible to learn social policy lessons for other national \\ institutional contexts as well.
}




\section{Introduction}

One of the main purposes of pensions, from an individual point of view, is to smooth consumption over the lifetime by consuming less than one is producing during working life and saving so that one can continue to consume when reaching old age (Barr 2004). The adequacy of this postretirement income, however, does not usually depend solely on how much an individual decides to save, but rather on how the state organizes the distribution and redistribution of these savings. Pension systems can sustain, diminish or increase income differences (Hardy 2009). Because pension systems differ across countries, pension income differences exist not only between countries, but inequalities also exist within countries (Disney and Whitehouse 2002; Ebbinghaus 2011). There is a growing recognition of the role of national institutional contexts in shaping life course, retirement patterns as well as economic well-being in retirement (Fasang 2010; Fasang 2012; Fasang, Aisenbrey, and Schömann 2013; Madero-Cabib and Fasang 2016; Mayer 2005).

One strand of empirical life course research emphasizes the importance of processes and events that take place earlier in life on financial well-being in retirement. These can include education, family formation, occupational trajectories, and spells of illness and unemployment (Crystal, Dennis Shea, and Krishnaswami 1992; Fasang, Aisenbrey, and Schömann 2013; HalpernManners 2015; Madero-Cabib and Fasang 2016). Such studies are usually designed to analyze the association between the occurrence and timing of earlier events on the one hand, and levels of retirement income, on the other. Another strand of research emphasizes the continuity and accumulation of income inequalities over the life course (Hungerford 2007; O’Rand 1996; Prus 2000).

Less attention has been paid to the late career period and the transition from work to retirement. Yet this is a period during which life courses and institutional contexts are particularly closely intertwined, with deep impacts on the retiree's financial well-being. Shaped by their life courses, older workers act as ‘agents’ and have preferences for either early exit or extended careers. 
At the same time, the institutional context acts as a 'structure' that determines what types of retirement are possible and attractive (Higgs et al. 2003). For example, after a long working life, a worker may decide that it is time to retire, but the pension system will determine whether that worker has accrued sufficient pension rights or whether early retirement will be penalized. Or, an older worker may fall ill and be unable to continue to work, while the disability pension system will determine if retirement is possible and under what financial conditions. As life courses differ, the financial outcomes of retiring can therefore be highly divergent within the same pension system.

The aim of this article is to analyze the relation between types of trajectories from work to retirement and changes in income in the years before and after retirement in Finland. Using a unique and detailed longitudinal register-based dataset that captures the structuring complexity of the Finnish pension system, we illustrate how pension systems do not have just one type of economic outcome for older workers and retirees, but a multiplicity of long-term effects on income. Retirement in Finland has specific features that make it an instructive case. The Finnish pension system can be best described as a hybrid design which combines statutory, occupational and private features (Kangas and Luna 2011). There is a flexible statutory retirement age ranging from 63 to 68, with financial incentives for working longer. Furthermore, there are several institutional pathways to early exit. By dissecting each of these features, we aim to not only draw conclusions for Finland, but generalize our findings to other countries where one or more of such features are in place.

\section{Individual income trajectories in later life}

Personal and household income typically follow a bell-shaped curve during working life. Income tends to rise from early adulthood until midlife, after which it slowly starts to decline again until retirement (Hardy 2009). After retirement, income usually drops, as the replacement rate of pensions is lower than previous earnings. Figure 1 exemplifies a typical income trajectory from 
mid-career through to later life. The period from midlife until retirement is indicated by the slightly downward sloping line A. Withdrawal from paid employment and entry into retirement (point R) is followed by a drop in income level (indicated with B). The individual pension replacement rate equals one minus the ratio of B to previous earnings. After retirement, income levels usually remain stable, as pension income is evenly spread over the years in retirement (line C).

\section{$<$ Figure 1 about here $>$}

\section{The role of pension systems}

The individual replacement rate is determined by the pension system. Pension systems can have three types of effects on income (re)distribution: status levelling, status maintenance and status divergence (Crystal and Waehrer 1996; Hardy 2009; Pampel and Hardy 1994; Prus 2000). These effects can be broadly related to the various tiers that make up the pension system (Ebbinghaus 2011). First, pensions can have status levelling outcomes, by reducing income disparities in the population after retirement. The role of status levelling is usually performed by the first tier of the pension system, in the form of a basic or minimum pension that is independent of earnings history. It is often aimed at securing minimum income levels. The larger the status levelling role of pensions, the larger the size of B for wealthier households and the smaller its size for poorer households.

Second, pensions can have status maintenance outcomes, by upholding income disparities in the population that already existed before retirement (Henretta and Campbell 1976; Hungerford 2007). Status maintenance is usually reinforced by the second tier of the pension system, consisting of earnings-related or occupational pensions whose level depends on work history and previous earnings. With status maintenance, the size of B is in theory proportional to previous earnings. 
Third, pensions can lead to status divergence, or cumulative advantage/disadvantage outcomes (Dannefer 2003; DiPrete and Eirich 2006; O’Rand 1996). This means that existing income disparities in the population are reinforced and increased by the pension system. During working life, retirement savings and investments accumulate at a higher rate for those who had not only more wealth, but also health and human capital to start with. Status divergence is often the result of the third tier of the pension system, exemplified by individual savings schemes that top up the other two tiers. In systems where the role of status divergence is emphasized, the relative size of B decreases when previous earnings are higher (cumulative advantage) and increases when previous earnings are lower (cumulative disadvantage).

Many pension systems incorporate elements of all three tiers. On a country level, they can create status levelling, maintenance and divergence outcomes all at the same time. A system's final redistributive outcomes are determined by the relative weight of each of the tiers (Ebbinghaus 2011). Traditionally, whereas the social democratic/Nordic welfare states have placed greater emphasis on status levelling by providing generous national basic pensions, conservative/continental welfare states have institutionalized status maintenance by relying on earnings-related occupational schemes (Bonoli 2000). Liberal or Anglo-Saxon countries, on the other hand, have left more room for status divergence by relying on individual schemes that top up minimum level basic pensions (Warner 2016).

Additionally, each tier of the pension system can have divergent outcomes on the income redistribution in the total population, as each of them might affect some groups within society more than they might affect others. A generous universal basic pension can increase the level of income at the lower end of the income distribution, thereby creating a status levelling effect. Maximum limits to pension benefits and progressive taxation can cause status levelling by targeting higher incomes (Prus 2000). The second tier can maintain the gender gap in retirement income when pensions are strongly earnings-related and dependent on the length of the work 
history (Ginn and Arber 1991; Gough 2001). This effect has been found primarily, though not exclusively, in traditional male-breadwinner societies where women take longer career breaks after childbirth and are more often employed in part-time jobs (Fasang, Aisenbrey, and Schömann 2013; Madero-Cabib and Fasang 2016). Vulnerable groups of retirees with, for example, fragmented work careers due to illness and unemployment, accumulate disadvantages in retirement income over the lifetime in almost any pension system. Cumulative advantage effects might apply only to the most well-off who can use specific occupational or private schemes to accumulate substantial wealth over the life course.

\section{Income and retirement trajectories}

In economic theory, the timing of retirement is often portrayed as the result of income and accumulated ‘pension wealth’. (Blöndal and Scarpetta 1999). In the sociological retirement literature, this microeconomic view of a single transition into retirement as an individual financial decision has been extensively criticized as too simplistic (see, e.g., Hofäcker 2010). First, enabling factors play a role, such as self-fulfilment at work and embeddedness in family and social networks (Higgs et al. 2003). Second, restrictive factors, such as illness and unemployment, determine the individual's possibilities to continue work. Third, the institutional context provides a set of structural incentives that the individual responds to (Fasang 2010; Mayer 2005). Especially in European countries, retirement has been structured by the presence of early exit pathways that bridge the period between exit from a career job and entrance into the old-age system (Ebbinghaus 2006; Kohli and Rein 1991).

These early exit pathways shape retirement as a trajectory, rather than a single transition in time. Whereas each individual trajectory is unique, an institutional context with strong structuring incentives can create typical retirement patterns (Fasang 2010). Studies on retirement trajectories in Germany and the UK (Fasang 2010) and the Netherlands (Author 2016) have shown 
that such typical trajectories vary by timing and by pathway of exit, including through various schemes such as unemployment benefits, disability benefits, occupational pensions and nonemployment.

Along with other socioeconomic factors, income has been found to be associated with retirement trajectories (Fasang 2010; Author 2016). 'Involuntary’ trajectories such as those through disability and unemployment are more common among lower income groups. People with higher incomes are more likely to have the freedom to choose the timing and route of their retirement. At the same time, it is likely that through the pension system and exit pathways, the timing and route of retirement determine the level of pension income. This is particularly the case when retirement is not an entirely individual and voluntary decision. In a pension system with strong status levelling features, early exit on an unemployment or disability pension can actually improve the level and stability of income for lower income groups. In a pension system with strong status maintenance or divergence features and with no alternative exit pathways for unemployment or disability, early retirement is more likely to induce a permanent reduction in pension income, hitting lower income groups the hardest (Ebbinghaus 2011; Warner 2016).

\section{The case of Finland: a hybrid pension system with a variety of exit pathways}

In the remainder of this article, we investigate how the pension system and exit pathways have shaped retirement and income trajectories in Finland. We look at the effects of the pension system on changes in income before and after retirement in the Finnish population as a whole, but do so by disentangling the components that have status levelling, maintenance and divergence effects for specific groups in the population. The Finnish case is instructive because the pension system features a dominant earnings-related pension, but also guarantees a minimum income and taxes higher pension incomes. Moreover, the institutional context strongly structures retirement through 
various exit pathways. By disentangling the effects of pension system tiers and exit pathways, it is possible not only to identify their specific impact in the Finnish case, but also to gain insight into their redistributive effects in a more general context.

The main tier of the Finnish pension system is its second tier, the statutory earningsrelated pension. It covers those who have contributed during their working lives and who meet certain minimum requirements of accrual. This second tier is divided between the private and public sectors, which have somewhat different ways of financing. The first tier is the so-called 'national pension', which covers all permanently resident in Finland and which is financed by the state. An additional 'guarantee pension' ensures a minimum income level on top of the national pension and earnings-related pensions. In 2014, 93 per cent of recipients received their pension from the earnings-related scheme, 43 per cent from the national pension scheme, and 36 per cent from both the national and earnings-related pensions (ETK and Kela 2015). The national pension was the only source of pension income for just 7 per cent. In addition to these two main tiers, there is a third tier of private pensions or life insurance schemes (Kangas and Luna 2011). ${ }^{1}$

Figure 2 depicts how in the Finnish system the level of earnings-related pensions is strongly dependent on the level of previous earnings. There is no upper limit to the amount of earnings-related pension that can be received. This should contribute to a strong status maintenance effect. The amount of national pension (and guarantee pension) received is dependent on amount of statutory earnings-related pension and is paid on top of it. It is means-tested and has an upper limit. In 2016, the guarantee pension was set at the level of $766.85 € /$ month, whereas the maximum amount of national pension was $634.30 € /$ month for those living alone (562.62 €/month for cohabitants), with a combined ceiling of $1311.05 € /$ month (1167.71 $€ /$ month for cohabitants) (Knuuti and Ritola 2016). Figure 2 also shows how the national and guarantee pensions raise incomes at the lower end of the distribution and create a status levelling effect. As a result of 
taxation, higher incomes are reduced to some extent (indicated by the thick line representing income after taxes), contributing to status levelling.

\section{<Figure 2 about here $>$}

There are different types of pensions within the national and statutory earnings-related pension system. Under the national pension system, an old-age pension can be drawn at the age of 65 , although it is possible to receive an early retirement pension at 63 , with benefits reduced by 0.4 per cent for each month of retiring early. In the earnings-related pension system, the old-age pensionable age is flexible between 63 and 68. Retiring at the earliest eligibility age is not penalized, but those who postpone retirement and continue working accrue pension entitlements at an increased 4.5 per cent rate of earnings. Earnings-related early old-age pension can be withdrawn at age 62, with a penalty of 0.4 per cent for each month of retiring earlier. Because early retirement on an old-age pension is penalized, it is expected to be more common among older workers with a relatively high income and sufficient years of pension accrual to secure an adequate retirement income. Therefore, being able to retire early while retaining a relatively high income suggests a cumulative advantage outcome.

People who move from a full-time to a part-time job between ages 61-67 are entitled to an earnings-related part-time pension that is proportional to the reduction in working hours. Parttime pension benefits are 50 per cent of the difference between full-time and part-time earnings. As a result, part-time pensions are more common among those with long working lives and with middle to higher incomes, ensuring an adequate retirement income (Salonen and Takala 2011). Therefore, as in the case of early retirement, retiring on a part-time pension is expected to have cumulative advantage outcomes.

A dominant early exit pathway in Finland has been the so-called 'unemployment tunnel'. The long-term unemployed born before 1950 and on unemployed benefits for the maximum period of time have been eligible to receive an unemployment pension. Unemployment pensions 
were converted into old-age pensions from the age of 62 (later 63). More recently, the unemployment pension was replaced by an extended earnings-related unemployment allowance, which effectively maintains the 'unemployment tunnel' to retirement. As the 'unemployment tunnel' has been a more common option in lower-paid and declining sectors, such as manufacturing and forestry, those who entered the tunnel were likely to have a lower income (Hytti 2004). It is assumed that the national and guarantee pensions ensures them with a relatively generous retirement income (status levelling outcome). At the same time, however, it is possible that longterm and recurrent unemployment over the life course has permanently reduced their pension wealth under the earnings-related pension scheme (cumulative disadvantage outcome).

A full disability pension becomes available in case of severe chronic health impairments and after a year of sickness benefit receipt. Partial disability pensions can be awarded in instances of a 40-60 per cent reduction on working capacity. Rehabilitation pensions are assigned for a limited duration only. Disability pensions assigned before 2006 were converted into old-age pensions from the age of 65; those awarded later are converted into an old-age pension at 63. In case of disability, it is expected that the Finnish pension system's effects on income are similar to those of the 'unemployment tunnel'. Disability pensions are more common among lower income groups (Leinonen, Martikainen and Lahelma 2012). Transition to a disability pension can, on the one hand, mean a stabilization and relative improvement in income (status levelling outcome). On the other hand, long-term illness over the life course may have negatively affected pension accrual under the earnings-related pension scheme (cumulative disadvantage outcome). 


\section{Data and methods}

\section{Data}

We made use of a unique register-based dataset that combines several Finnish Centre for Pensions databases. The data include one cohort of Finnish nationals and residents born in 1948 with a follow-up period from 2005 to 2014, hence for the age bracket 57-66. This cohort and age bracket allowed the longest follow-up period for which the various data sources could be combined. Even though the new flexible retirement age means that Finns can work to age 68 with a higher pension accrual rate, very few actually do so. In 2010, more than 50 per cent of the eligible retirees retired exactly at the earliest possible age of 63 (Tuominen 2013). In the same year, around 95 per cent had retired by age 65 . A single birth cohort is somewhat a limitation, but the terms of retirement were substantially the same for this and for the slightly younger and older cohorts. The lower age limit for old-age retirement will begin to rise from 2018 onwards, which may change retirement patterns in the future.

All individuals in this dataset were still in employment on the last day of 2004, were of Finnish nationality and resided in Finland during the follow-up period ( $N=55,971)$. This selection was made to capture those individuals still active in the labor market at age 56 and to be able to follow their paths towards retirement. The inclusion of those who were already permanently outside the labor market at 56, due to disability or unemployment, would not have added to our understanding of the income trajectories of Finnish workers around the time of retirement. The dataset combines detailed information on employment spells, spells of pension receipt, spells of various types of benefit receipt, and income from employment (per year) and earnings-related pensions (per month). 


\section{Retirement trajectories}

We identified retirement trajectories on the basis of employment, benefits and pension spells with the aid of sequence and cluster analysis (Abbott 1995). The strength of sequence analysis is that it allows grouping together the most similar sequences and separating the most dissimilar. Instead of studying retirement as a single transition, sequence analysis allows us to see 'single events in their continuity' (Aisenbrey and Fasang 2010, 421). In the context of this study, it made an analysis of how timing and pathway of exit combine possible.

We recoded the data into 13 main statuses: employed, sickness benefits, unemployment benefits, other benefits, full disability pensions, rehabilitation pensions, partial disability pensions, unemployment pensions, early retirement pensions, part-time retirement pensions, old-age retirement pensions, other pensions and deceased. We created individual sequences of primary monthly income sources with a length of 97 months from the month of turning 57 (in 2005) until the month of turning 65 (in 2013).

Optimal matching (OM) techniques were used to calculate the distances between the sequences (Gabadinho et al. 2010; Han and Moen 1999; Fasang 2010). OM was applied because it allows for analyzing sequences of unequal lengths. The lengths of the sequences varied because we were unable to reconstruct them for the full age bracket on the basis of our spell data. Other distance measures that are commonly used when the timing of transitions is of particular importance, such as the dynamic Hamming distance measure (Aisenbrey and Fasang 2010; Fasang 2010), can only be applied to sequences of equal length. We decided to set the substitution costs manually based on our understanding of the Finnish social security and pension system. We tested several alternative solutions with different cost settings and using transition rates between statuses to determine the costs, but found that those results that poorly reflected the reality of Finnish retirement. We nonetheless briefly comment on these alternative solutions in the results section. 
The substitution cost matrix used for calculating the distances is provided in the Annex. We grouped together statuses by theme (e.g., sickness benefits, rehabilitation pensions and disability pensions representing statuses related to health) and by type (employment, benefits, parttime pensions and pensions). Statuses similar by theme and type were given a lower substitution cost. Transitions between statuses that were dissimilar by theme or type were assigned higher costs. The cost for transitions to 'deceased' as the ultimate 'absorbing state' was set as the highest. As the timing of the transitions between statuses are of theoretical importance in analyzing retirement, indel costs were set at 2.1, slightly higher than 0.5 times the highest substitution cost, resulting in them not being used (Aisenbrey and Fasang 2010).

\section{Dependent variables}

We analyzed the change over time in three dependent variables: 1) annual total income from earnings and earnings-related pensions only, 2) annual total gross income from earnings and all pensions, and 3) net income, which equals gross income minus taxes. Comparing 1) and 2) allowed for estimating the potential redistributive effects of the national and guarantee pensions on retirement income, whereas comparing 2) and 3) allowed for estimating the potential redistributive effects of the tax system on income in general.

One shortcoming of the data was that it provided no information on income from various types of benefits. In those years with longer spells of benefit receipt, earnings were low or income was even zero. Therefore, we marked every year in which more than one month was spent in sickness or unemployment as missing and used the multiple imputation procedure in SPSS to simulate the yearly earnings that would have been received in the absence of benefit spells, based on patterns in earnings in preceding years and among peer groups (Acock 2005). This was primarily done for practical reasons, as it allowed us to calculate net income and analyze the redistributive effects of the Finnish tax system. We tested whether our results are robust when comparing our models with imputed values with models that include the original, and lower, values for income, 
while controlling for days of absence. The latter yielded very similar results and confirmed the robustness of the main fixed effects (see supplementary materials). Therefore, we argue that, while being cautious in our interpretations, the data and our results provide a valid representation of the development of earnings over a longer period.

Benefit spells in the late career can be considered as a transitional phase between employment and retirement. Previous studies have already shown that the transition from benefits to pensions results in status levelling (Rantala and Suoniemi 2011), whereas this study focuses on the redistributive effects of the pension system over the life course. Therefore, we argue that it is possible to disregard benefits as a source of income in our analysis and simulate earnings from work instead. As a result, our analyses obviously overestimate the real income received by those in long spells of unemployment and sickness before their retirement. It is difficult to provide a precise magnitude of this overestimation, but in the supplementary materials, we present the average yearly days of benefit receipt of each of the groups under scrutiny. It should be noted that in Finland in 2005, the net replacement rate of unemployment benefits for an average production worker was around 72 per cent, while the net replacement rate of sickness benefits was around 57 per cent (Scruggs, Jahn, and Kuitto 2014).

The pension income data only included information on statutory earnings-related pensions. This information was sufficient to calculate the levels of the national and guarantee pensions. ${ }^{2}$ National pensions are only paid if they amount to at least $6.74 €$ per month. Earningsrelated and national pensions are topped up to $766.85 €$ per month by the guarantee pension if the former two amount to less than $760.11 €$. For those claiming an old-age pension or early retirement pension before 65 , we used a discount rate for the national pension of 0.4 per cent for each month that the pension was drawn before the month of turning 65 .

As we lacked information on cohabitation, all calculations were done assuming that the persons lived alone. In the ideal case, incomes should be calculated at the household level, but 
this was not possible on the basis of our data. Also, survivor's pensions were not included. Still, calculating the pensions with the assumption of single-living individuals can give a good estimation of the pension system's income effects. The Finnish pension system, as indeed the Nordic welfare model in general, is based on the idea of universal social rights for individuals, even though spouses' income or pension entitlements have potential cushioning effects in case of economic deprivation (Fritzell, Bäckman, and Ritakallio 2012). Therefore, spouse’s earnings and pensions and survivor's pensions would in fact have increased the incomes of especially women and households at the lower end of the income distribution (Rantala and Riihelä 2016).

Total earnings and pensions from various sources were added for each year from 2005 to 2014 to calculate annual gross income. Subsequently, annual net income was calculated on the basis of gross earnings and pensions using a simulation model provided by the Finnish Centre for Pensions. This model takes into account income taxes, various deductions and municipal taxes. ${ }^{3}$ Again, this was done with the assumption of single-living households.

\section{Independent and control variables}

To estimate individual change in income over time, we included a continuous variable indicating the year, ranging from 1 to 10 (Singer and Willett 2003). A dummy variable was included for an individual being retired in each particular year. The first year when someone’s income from pensions exceeded income from earnings was assumed the year of retirement. Starting from the year of retirement, the number of years in retirement was included in the models as a continuous variable. The various clusters of retirement patterns were included in the models as a series of dummy variables, with 'Standard retirement' as the reference group.

Dummies were included for women and public sector employment as control variables. Although women's work histories in Finland, as indeed in many other countries, are often interrupted by childbirth and subsequent childcare (Halpern-Manners et al. 2015; Madero- 
Cabib and Fasang 2016), women usually return to full-time work and pension accrual is not affected by parental leave. However, there is a gender gap in earnings: women tend to work in lower paid jobs than men and earn less, resulting in a gender gap in retirement income as well (Ginn and Arber 1991). A recent study by Rantala and Riihelä (2016) showed that in 2013, Finnish women’s earnings-related pension equaled only 66 per cent of men’s.

Sector of employment is expected to have an effect on both the timing and pattern of retirement and on the replacement rate of pensions. In Finland the pension system was regulated separately for private and public sector employees until 1996, when the systems were largely harmonized. However, workers in different sectors still contribute to different pension funds, which not only affects their pension levels, but also the timing of their pension take-up. Moreover, employment in the public sector is more stable and secure than in the private sector, and provides better opportunities to adjust working conditions for an ageing staff. The earnings data for the selfemployed was found to be underreported and therefore this group was excluded from further analyses.

Finally, we controlled for the number of years in working life since age 18 in the year 2005. The level of earnings-related pensions depends to a large extent on the number of years worked and the earnings-related pension benefits accrued during that time. Hence, it is to be expected that those with longer working lives have a higher pension replacement rate. Moreover, the variable also controlled for the possibility that those who entered working life at an earlier age also retired earlier.

Those who died during the follow-up were excluded from the subsequent analyses because their income trajectories were incomplete. We checked for the risk of selective mortality because of the likelihood of this subgroup being atypical for the whole population. Mortality was higher among men than among women: among those who died, 65.4 per cent were men. A t-test confirmed that at the time of turning 57, mean income, both gross and net, was lower among those 
who died than among the rest of the population. However, their mean income did not differ significantly from those who exited the labor market through unemployment or disability. We also did not find a statistically significant difference in the length of their working lives compared to the rest of the population. Moreover, as this is a small subgroup (2.6 per cent of the study population), we do not believe that excluding them mitigates the validity of our findings.

\section{Models}

We used the natural logarithm of income (earnings plus pensions) as the dependent variable. We estimated multilevel or mixed linear regression models for discontinuous change to estimate income trajectories over time, with individual change in income over time at level 1 and variation between subjects at level 2 (Singer and Willett 2003). We assumed that change is discontinuous: a drop in income is expected when people move from work into retirement. A slightly simplified specification of the full model is as follows:

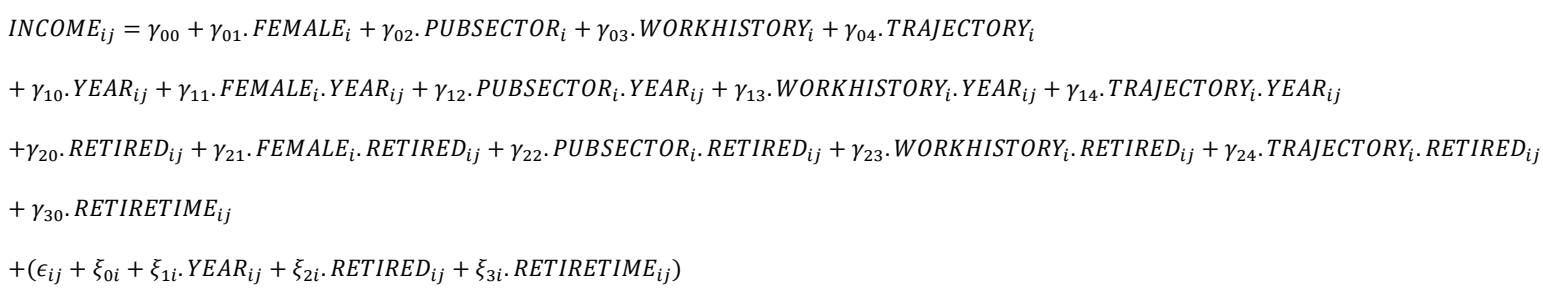

The first row of the equation represents the level of the intercept and the fixed effects of the various subgroups (gender, sector, length of working life and type of trajectory) in relation to the intercept. In terms of Figure 1, these estimates correspond to the position where line A intersects the $y$-axis. The second row of the equation estimates the slope of the income trajectories by interacting the year variable with the subgroup dummies. These estimates correspond to the slope of line A in Figure 1. The third equation row estimates the change in income level at the moment of retirement (B in Figure 1). Interacting the 'retired' dummy with the subgroup dummies estimates the variety of change among retirement trajectory, gender, sector, and work history. Equation row four defines the slope of the income trajectory after retirement (line $C$ in Figure 1), estimated by 
using the number of years since retirement. We did not estimate the differences in slopes for the various subgroups, as we assumed that changes in income after retirement did not differ for the various retirement trajectories. If such differences existed, they would be beyond the scope of this study. Row five specifies the error terms and random part of the model. We do not report the results of additional tests that confirmed the models’ assumptions that residuals are normally distributed, and the variance between the different time points can be considered equal (Singer and Willett 2003).

In reporting our results, we focus on the fixed effects. By using fixed effects in our models, we can control for the stable characteristics of individuals and reduce the risk of bias. We paid special attention to how the initial income of the various trajectory and control variables differed from the intercept and to the interactions of the 'Retired' variable with the trajectory and control dummies. These represent the main indicators of how the income positions these specific groups develop in relation to the total population. We interpret the results for each of the trajectory and control variables and their interactions with the 'Retired' variable according to the criteria described in Table 1. The estimate for the fixed effect dummy indicates how the initial income of a certain group differs from that of the reference group (men working in the private sector with 'Standard retirement') at the intercept, i.e. at age 57. The estimate for its interaction with 'Retired' indicates whether the decrease income of each specific group is smaller or greater than that of the reference group at the time of retirement. For instance, a positive estimate of the fixed effect dummy means relatively higher initial earnings and a positive estimate for the interaction term means a relatively higher pension, indicating a cumulative advantage effect for that particular group.

\section{< Table 1 about here $>$}

\section{Findings}




\section{Sequence analysis}

Figure 3 shows the results for an eight-cluster solution following sequence analysis with OM on the whole study population. The weighted Average Silhouette Width (ASW) ${ }^{4}$ of the cluster solution is 0.36, which indicates that the data is reasonably structured (Studer 2013). We chose this as the optimal solution as it closely represented the main exit pathways for the period under study and corresponded to our theoretical expectations. Solutions with alternative substitution cost settings showed the relative robustness of these clusters, yielding similar results especially for the 'Standard retirement', 'Late retirement' and 'Unemployment' clusters, and distinguishing between a 'Disability' and a 'Long-term disability' trajectory. More variation was found in the clustering of the 'Part-time retirement' and 'Early retirement' trajectories.

The largest cluster, 'Standard retirement' $(N=23,686)$, includes those who worked until the age of 63, possibly experienced short periods of unemployment or part-time retirement, and then retired on an old-age pension. 'Late retirement' $(N=11,016)$ consists of those who worked until at least 64 or who were still working at the time of turning 65 . 'Early retirement' $(N=4,638)$ represents a group that by the age of 61 had already largely retired, partly through special farmers’ pensions. Those who exited through 'Part-time retirement' $(N=3,743)$ mostly retired on a part-time pension between ages 58 and 60, before taking an old-age pension between ages 63 and 65 .

\section{$<$ Figure 3 about here $>$}

'Involuntary’ retirement routes are represented by 'Unemployment’ $(N=5,883)$, 'Disability' $(N=3,151)$ and 'Long-term disability' $(N=2,423)$. Those in the 'Unemployment' route primarily retired on an unemployment pension from unemployment benefits at the age of 61, until drawing an old-age pension after turning 63. The difference between the two disability routes is that 'Disability' mainly includes those for whom the insured event (illness or injury) took place after year 2006 and who could access an old-age pension at the age of 63. Those in 'Long-term disability' had their insured event before 2006, and they continued to receive a disability pension 
until the age of 65. The transition from disability pension to old-age pension is purely technical and has no effect on pension income. As we found no differences between the two disability clusters apart from the timing of entrance, we collapsed them into one category in the multilevel models. Finally, the 'Death' cluster $(N=1,431)$ includes those who died during the follow-up period and were excluded from further analysis.

\section{Descriptive statistics}

Table 2 describes the models' explanatory variables. It shows that differences in the proportions of trajectory take-up between men and women were small, yet statistically significant $\left(\chi^{2}(6)=141.93\right.$, $p<0.01)$. Differences between sectors were more considerable $\left(\chi^{2}(6)=2615.50, p<0.01\right)$. Especially 'Standard retirement' and 'Unemployment' were more common in the private sector, whereas in the public sector 'Late retirement' and 'Early retirement' were more frequent. The last column of Table 2 shows that retirement timing is related to the total number of years in the labor market and of pension accruals, considering that those in the 'Late retirement' trajectory on average had the shortest working lives and those in 'Early retirement' the longest.

\section{<Table 2 about here $>$}

Figure 4 presents the levels of average annual gross total income and net total income, and income from earnings and pensions separately. It shows that, after slightly rising until the age of 60, average total gross income drops from 32,639 € among those aged 57 to 26,734 € among those aged 66. Average net income shows a steadier development over these 10 years, most probably because of the higher rate of tax on earnings than on pensions. Unsurprisingly, income from earnings followed a steep downward slope, while the share of pensions increased sharply between ages 57 and 66 . 


\section{Multilevel regression models}

Table 2 shows the estimates for the multilevel regression models with log-transformed income from earnings and earnings-related pensions only (Models 1 and 4), total gross income (Models 2 and 5) and total net income (Models 3 and 6) as dependent variables. Comparing the results for the three types of income as dependent variables allows us to analyze the overall redistributive effects of the pension tiers and taxation. The real income amounts and proportional differences can be obtained by using exponential functions of the parameters in the model.

The first three models only include the basic parameters: the intercept, the average annual change in income ('Year'), average change in income when transitioning into retirement ('Retired') and the average annual change in income after retirement ('Years in retirement'). These enable us to estimate the income trajectories and the overall redistributive effects of the pension and tax system for the whole study population. The intercept indicates the average 'initial' income level in 2005, which was 28,710€ $\left(e^{10.265}\right)$ based on earnings and earnings-related pensions (Model 1), 28,681€ $\left(e^{10.264}\right)$ gross (Model 2) and 19,732€ $\left(e^{9.890}\right)$ net (Model 3). The 'Year' estimate indicates that gross income increased each year by 0.01 per cent and net income by 1.5 per cent. After retirement, gross income decreased by 0.3 per cent per year and net income decreased by 1.3 per cent, based on the estimates for 'Years in retirement'.

As expected, entering into retirement was accompanied by a substantial drop in income. Comparing the 'Retired' estimate in the three models shows how the pension and tax system affected this replacement rate. Based on earnings-related pensions alone, the average decrease in income would have been 25.1 per cent (Model 1). The national and guarantee pensions, by raising the retirement income among lower income groups, reduced this average decrease to 21.7 per cent (Model 2). After taxes, the average decrease in net income was only 16.8 per cent (Model 3). This indicates that gross and net income from pensions was lower than income from earnings, 
but that the tax system increased the average net replacement rate of pensions in the whole population.

\section{<Table 2 about here>}

The longer one’s work history, the higher one’s initial income. Each year worked increased net income with 2.5 per cent gross and 2.2 per cent net. The interaction estimate of 'Work history' with 'Retired' shows that the number of years worked substantially affected the level of earnings-related pension, increasing it by 1.6 per cent for each year (Model 4 in Table 2). This was expected, as earnings-related pensions are determined by career length. However, this effect decreased for total gross income (Model 5) and disappeared for net income (Model 6). On average, women earned 23.5 per cent less than men gross and 19.0 per cent net. In retirement, women’s income dropped at a higher rate than men's, although this effect was small. Hence, the results suggest that the pension system had a status maintenance or slight cumulative disadvantage effect on women's income. The national and guarantee pensions and the tax system had relatively little impact on the size of these effects. Those who worked in the public sector had somewhat higher initial earnings, about 4.0 per cent gross and 3.3 per cent net. Their income in retirement was also higher: 9.3 per cent gross and 7.0 per cent net. This suggests that pension accrual in the public sector created a cumulative advantage outcome.

Those in the 'Late retirement' trajectory had an initial pre-retirement income that was about 6 per cent higher, both gross and net, than in the reference group, and it continued to grow at a higher rate. When they retired, however, their income dropped by a larger proportion of 10.6 per cent gross and 8.6 per cent net. This suggests a status levelling outcome for those retiring late. It appears that the national and guarantee pensions increased the status levelling outcome compared to earnings-related pensions only, but taxes reduced it again.

'Early retirement' was also more common among workers with a higher initial income, but after retiring they enjoyed a pension income that was about 6 to 7 per cent higher. This 
suggests a cumulative advantage outcome: as well as enjoying higher earnings and a higher pension, those in 'Early retirement' were able to withdraw from the labor market earlier. The national and guarantee pensions and the tax system had little impact on their pension's replacement rate.

The 'Part-time retirement' trajectory also shows a cumulative advantage outcome, especially because this group was able to reduce working hours partially without severe loss of income. Initial income was somewhat higher, but statistically significantly so only for net income. After retirement, gross income was reduced by only 18.6 per cent and net income by 10.5 per cent. The pension and tax system had some redistributive effects, though, and levelled out some of the financial advantage that part-time pensioners seemed to have.

Unsurprisingly, those in 'Unemployment' had the lowest levels of initial income: 29.4 per cent lower gross and 24.4 per cent lower net than the reference group. After retirement, however, their income fell by about 5 per cent less. This indicates a small status levelling outcome of retiring on an unemployment pension. This effect can be attributed to the guarantee and national pensions and to taxes. Without them, there would have been a cumulative disadvantage effect, as the reduction in income would have even been larger for those in 'Unemployment' than for the reference group (Model 4).

Similarly, retirement through 'Disability' was accompanied by a status levelling effect. In this trajectory, initial income was 18.2 per cent lower gross and 14.6 per cent lower net than in the reference group. After retirement, replacement rates were higher by 10.2 per cent gross and 8.2 per cent net. The guarantee and national pensions and the tax system also had a further redistributive effect in the case of 'Disability', although not as strong as in the case of 'Unemployment'.

\section{Discussion}


Theoretical and empirical sociological research has extensively studied how life courses affect financial well-being in retirement and how this might differ in various institutional contexts (Fasang, Aisenbrey, and Schömann 2013; Halpern-Manners et al. 2015; Madero-Cabib and Fasang 2016; O’Rand 1996; Pampel and Hardy 1994). Less attention has been paid to how the institutional context, and the pension system in particular, co-determines income at the time of retirement as a major life course event. We theorized that features commonly attributed to pension systems as a whole (status levelling, maintenance and divergence) also occur simultaneously within the same pension system for various groups in society. This is the case especially when a pension system is multi-tiered and when there are alternative exit pathways. Our high-quality and detailed dataset offered the opportunity to study individual intra-cohort income trajectories before and after retirement in Finland and to disentangle the impact of exit pathways, retirement timing and the pension system.

The Finnish pension system combines typical features of Nordic and continental welfare states (Bonoli 2000). It has a basic pension under the first tier. However, the level of basic pension is dependent on the level of earnings-related pension accrued under the second tier. In that sense the Finnish system is similar to the current Swedish system, but different from the Danish or Dutch systems, for example, where a basic pension is provided to all and earnings-related pensions are paid on top of that. As expected, we found that the level of earnings-related pensions is heavily dependent on the number of years worked. The presence of the national and guarantee pensions and taxation, however, ensured a substantial status-levelling outcome and reduced the impact of career length on pension benefits.

In terms of women's labor market participation, Finland is closer to the Nordic dual earner model than to the continental traditional breadwinner societies. Women's employment rates are higher than men's and their attachment to full-time work remains high throughout the life course, even in the case of career breaks due to childbirth. Therefore, we expected to find less of a 
gender gap in retirement income than in more traditional male-breadwinner societies such as Germany or Switzerland (Fasang, Aisenbrey, and Schömann 2013; Madero-Cabib and Fasang 2016). Nevertheless, there was a substantial gender gap in retirement income, although our results confirmed earlier findings that this was primarily due to relatively lower earnings over the life course affecting pension accrual (Rantala and Riihela 2016). This outcome implies status maintenance. At the same time, women were more likely to work in the public sector, which potentially improved their pension income.

Finland has been closer to the continental welfare model in the sense that it has had a stronger early exit culture than the other Nordic countries (Ebbinghaus 2006; Hytti 2004). In order to identify the impact of early exit pathways on the variety in retirement patterns in Finland, we used sequence and cluster analysis to find the most typical retirement trajectories. The advantage of operationalizing retirement as trajectories is that we can take into account the range of possible retirement timing and the use of various institutional exit pathways. Although the eight main trajectories identified were specific to the Finnish context, there were many similarities to the six clusters in the United States, seven in the Netherlands, seven in Germany and eight in the United Kingdom found in previous studies (Calvo, Madero-Cabib, and Staudinger 2017; Fasang 2010; Author 2016). As in those studies, we found not only a large 'standard' or 'traditional' retirement trajectory, but also clusters of those who retired early and those who retired relatively late. Moreover, unemployment and disability pensions shaped distinct trajectories. Only 'Part-time retirement' constituted a distinctively Finnish trajectory that cannot easily be compared to part-time employment in other national contexts, as it made it possible to combine income from employment with partial pension benefits.

We found that the type of retirement trajectory was strongly associated with income trajectory, while the pension and tax system affected income differently in each of the retirement trajectories. We looked at redistributive outcomes for each of the trajectories with the 'Standard 
retirement' trajectory (42.3 per cent of the study population) as a reference group. The remaining retirement trajectories can be divided into three broad categories based on how the pension and tax system changed their income positions relative to the rest of the population.

First, the 'Early retirement' and 'Part-time retirement' trajectories, together 15.0 per cent of the study population, represented retirement with cumulative advantage outcomes. After a relatively long working life, this group not only enjoyed high incomes before retirement, but it also had higher pension replacement rates than those in the other trajectories while being able to reduce working hours or retire completely. Early retirement as cumulative advantage stands in contrast with liberal welfare states such as the United States and United Kingdom, where early retirement is often a result of push rather than pull factors and where penalization in the pension system is more likely to hit lower income groups (Ebbinghaus 2011; Fasang 2012; Warner 2016).

Second, those in the 'Late retirement' trajectory (19.7\%) enjoyed relatively high incomes before retiring, but experienced a steeper drop in income when they retired. This suggests a status levelling outcome of the pension system for this group. It is possible that there were financial reasons for these workers to remain active in the labor market, e.g. because they had entered the labor market later and had lower pension accruals. At the same time, it is possible that they did not retire late for financial reasons, but because of satisfaction with their work and being in a position to adjust to an extended working life. However, part of the individuals in this cluster had not retired by age 65 and therefore there was a greater risk that their retirement income was underestimated.

Finally, our results suggest a status levelling effect for those in the 'Unemployment' and 'Disability' trajectories, even though large income differences with the other groups persisted. In these trajectories, including 20.4 per cent of the study population, early labor market exit was more likely involuntary and due to displacement or health problems. Their considerably lower initial incomes indicated that they occupied a precarious labor market position. Although maintaining an overall lower income level, they had relatively higher pension replacement rates. 
This can be attributed to the redistributive effects of the Finnish guarantee and national pensions and taxes. Those in the 'Unemployment' and 'Disability' trajectories were among the largest recipients of unemployment and sickness benefits. If data on benefit income had been available, the status levelling effect of pensions for this group most likely would have been even larger.

This study was largely descriptive and exploratory in nature and further research is needed to identify causal relations. We studied the association of retirement trajectories with income trajectories, but refrained from concluding whether timing and type of retirement were determined by income or vice versa. Most literature focuses on the former, whereas we argued that the way institutions structure retirement also has an impact on pension income. Future research should include more cohorts and other countries to improve generalizability by controlling for country, cohort and period effects.

The detail of our Finnish data enabled us to disentangle the components of the Finnish institutional context and so to distinguish between the redistributive impact of tiers, exit pathways and taxation. O’Rand (1996) argued 20 years ago that in the American context, the elderly population is far from homogenous in terms of income. She identified a 'pension elite' and the 'pension poor' (O’Rand 1996, 232). From a comparative international perspective, Disney and Whitehouse (2002, 79-80) similarly found 'two nations of early retirees': those with generous early retirement benefits and private pensions and those forced to retire on low income due to illness or redundancy. Our research shows that income differences persist among retirees even in a highly structured context such as the Finnish one, but that social policy, through pensions and taxes, can mitigate these differences and improve the financial well-being of specific groups of retirees at risk. 


\section{Notes}

1. This third tier is not taken into account in the further analysis and constitutes only a small part of total pension incomes in Finland.

2. We used the 2016 rules for calculating the monthly national and guarantee pension levels in addition to the earnings-related old-age, disability and unemployment pensions (ERP), where, in euros:

$$
\begin{aligned}
& \text { National pension }=634.30-\frac{\text { gross } E R P-55.95}{2} \text {, and } \\
& \text { Guarantee pension }=766.85-\text { other pensions. }
\end{aligned}
$$

3. Excluding church taxes levied on members of the Finnish Lutheran church.

4. The ASW measure ranges from -1 to 1 and represents the 'coherence of the assignment of an observation to a given group, compared to the average weighted distance of an observation from the other members of its group and its average weighted distance from the closest group’ (Studer 2103, 14). 


\section{References}

Abbott, Andrew. 1995. “Sequence Analysis: New Methods for Old Ideas.” Annual Review of Sociology 21: 93-113.

Acock, Alan C. 2005. “Working with Missing Values.” Journal of Marriage and Family 67: 101228.

Aisenbrey, Silke, and Anette E. Fasang. 2010. “New Life for Old Ideas: The ‘Second Wave’ of Sequence Analysis Bringing the Course Back into the Life Course.” Sociological Methods \& Research 38(3): 420-62.

Barr, Nicholas. 2004. The Economics of the Welfare State. Oxford: Oxford University Press.

Blöndal, Sveinbjörn, and Stefano Scarpetta. 1999. “The Retirement Decision in OECD Countries.” OECD Economics Department Working Paper 1999-202. OECD.

Bonoli, Giuliano. 2000. The Politics of Pension Reform: Institutions and Policy Change in Western Europe. Cambridge: Cambridge University Press.

Calvo, Esteban, Ignacio Madero-Cabib, and Ursula M. Staudinger. 2017. "Retirement Sequences of Older Americans: Moderately Destandardized and Highly Stratified Across Gender, Class, and Race.” The Gerontologist (ahead of print publication).

Crystal, Stephen, Dennis Shea, and Shreeram Krishnaswami. 1992. "Educational Attainment, Occupational History, and Stratification: Determinants of Later-Life Economic Outcomes.” Journal of Gerontology 47(5): S213-21.

Crystal, Stephen, and Keith Waehrer. 1996. “Later Life Inequality in Longitudinal Perspective.” Journal of Gerontology: Social Sciences 51B(6): S307-18. 
Dannefer, Dale. 2003. “Cumulative Advantage/Disadvantage and the Life Course: Cross-Fertilizing Age and Social Science Theory.” Journal of Gerontology: Social Sciences 58B(6): S327-37.

DiPrete, Thomas A., and Gregory M. Eirich. 2006. “Cumulative Advantage as Mechanism for Inequality: A Review of Theoretical and Empirical Developments.” Annual Review of Sociology 32: 271-97.

Disney, Richard, and Edward Whitehouse. 2002. “The Economic Well-Being of Older People in International Perspective: A Critical Review.” In Annual Review of Gerontology and Geriatrics: Volume 22, 2002: Economic Outcomes in Later Life: Public Policy, Health and Cumulative Advantage, edited by Stephen Crystal and Dennis Shea, 59-94. New York: Springer.

Ebbinghaus, Bernard. 2006. Reforming Early Retirement in Europe, Japan and the USA. Oxford: Oxford University Press.

(ed.). 2011. The Varieties of Pension Governance: Pension Privatization in Europe. Oxford: Oxford University Press.

ETK and Kela (2015). Statistical Yearbook of Pensioners in Finland 2014. Helsinki: Juvenes Print.

Fasang, Anette E. 2010. "Retirement: Institutional Pathways and Individual Trajectories in Britain and Germany.” Sociological Research Online 15(2).

Fasang, Anette E. 2012. “Retirement Patterns and Income Inequality.” Social Forces 90(3): 685-711.

Fasang, Anette E., Silke Aisenbrey, and Klaus Schömann. 2013. “Women’s Retirement Income in Germany and Britain.” European Sociological Review 29(5): 968-80.

Fritzell, Johan, Olof Bäckman, and Veli-Matti Ritakallio. 2012. “Income Inequality and Poverty: Do the Nordic Countries Still Constitute a Family of their Own? In Changing Social Equality: The Nordic Welfare Model in the $21^{\text {st }}$ Century, edited by Jon Kvist, Johan Fritzell, Björn Hvinden, and Olli Kangas, 165-85. Bristol: The Policy Press. 
Gabadinho, Alexis, Gilbert Ritschard, Matthias Studer, and Nicolas S. Müller. 2010. Mining Sequence Data in $R$ with the Traminer Package: A User's Guide. University of Geneva. Available online at http://mephisto.unige.ch/pub/TraMineR/doc/1.4/TraMineR-1.4-Users-Guide.pdf [January 2014].

Ginn, Jay, and Sara Arber. 1991. “Gender, Class and Income Inequalities in Later Life.” The British Journal of Sociology 42(3): 369-96.

Gough, Orla. 2001. “The Impact of the Gender Pay Gap on Post-Retirement Earnings.” Critical Social Policy 21(3): 311-34.

Halpern-Manners, Andrew, et al. 2015. “The Impact of Work and Family Life Histories on Economic Well-Being at Older Ages.” Social Forces 93(4): 1369-96.

Han, Shin-Kap, and Phyllis Moen. 1999. “Clocking Out: Temporal Patterning of Retirement.” American Journal of Sociology 105(1): 191-236.

Hardy, Melissa. 2009. “Income Inequality in Later Life.” In International Handbook of Population Aging, edited by Peter Uhlenberg, 493-518. Dordrecht: Springer.

Henretta, John C., and Richard T. Campbell. 1976. "Status Attainment and Status Maintenance: A Study of Stratification in Old Age.” American Sociological Review 41(6): 981-92.

Higgs, Paul, et al. 2003. "Pathways to Early Retirement: Structure and Agency in Decision-Making among British Civil Servants.” Ageing \& Society 23: 761-78.

Hofäcker, Dirk. 2010. Older Workers in a Globalizing World. An International Comparison of Retirement and Late-Career Patterns in Western Industrialized Countries. Cheltenham and Northampton: Edward Elgar.

Hungerford, Thomas L. 2007. “The Persistence of Hardship over the Life Course.” Research on Aging 29(6): 491-511. 
Hytti, Helka. 2004. "Early Exit from the Labour Market through the Unemployment Pathway in Finland.” European Societies 6(3): 265-297.

Kangas, Olli, and Päivi Luna. 2011. “Finland: From Statutory Pension Dominance towards Voluntary Private Schemes.” In The Varieties of Pension Governance: Pension Privatization in Europe, edited by Bernard Ebbinghaus, 210-39. Oxford: Oxford University Press.

Knuuti, Juha, and Suvi Ritola. 2016. “Kokonaiseläke 2016. Katsaus työeläkkeen, kansaneläkkeen ja verotuksen määräytymiseen.” Eläketurvakeskuksen Raportteja 2016-1. Finnish Centre for Pensions.

Kohli, Martin, Martin Rein, Anne-Marie Guillemard, and Herman van Gunsteren (eds.). 1991. Time for Retirement. Comparative Studies of Early Exit from the Labor Force. Cambridge: Cambridge University Press.

Leinonen, Taina, Pekka Martikainen and Eero Lahelma. 2012. “Interrelationships between Education, Occupational Social Class, and Income as Determinants of Disability Retirement.” Scandinavian Journal of Public Health 40: 157-166.

Madero-Cabib, Ignacio, and Anette Eva Fasang. 2016. “Gendered Work-Family Life Courses and Financial Well-Being in Retirement.” Advances in Life Course Research 27:43-60.

Mayer, Karl Ulrich. 2005. “Life Courses and Life Chances in a Comparative Perspective.” In Analyzing Inequality: Life Chances and Social Mobility in Comparative Perspective, edited by Stefan Svallfors, 17-55. Stanford: Stanford University Press.

O’Rand, Angela M. 1996. “The Precious and Precocious: Understanding Cumulative Disadvantage and Cumulative Advantage over the Life Course.” The Gerontologist 36(2): 230-8.

Pampel, Fred C., and Melissa Hardy. 1994. "Status Maintenance and Change during Old Age.” Social Forces 73(1): 289-314. 
Prus, Steven G. 2000. "Income Inequality as a Canadian Cohort Ages. An Analysis of the Later Life Course.” Research on Aging 22(3): 211-37.

Rantala, Juha, and Marja Riihela. 2016. “Eläkeläisnaisten ja -miesten toimeentuloerot vuosina 1995-2013.” Eläketurvakeskuksen Tutkimuksia 2016-1. Finnish Centre for Pensions.

Rantala, Juha, and Ilpo Suoniemi. 2011. “Toimeentulon Muuttuminen Eläkkeelle Siirryttäessä Ekvivalenttitulosuhteen Tarkastelua.” Yhteiskuntapolitiikka 76(1): 3-16.

Salonen, Janne, and Mervi Takala. 2011. "Working Career and Income of Part-Time Pensioners in Finland.” Finnish Centre for Pensions Working Papers 2011-2. Finnish Centre for Pensions.

Scruggs, Lyle, Detlef Jahn, and Kati Kuitto. 2014. “Comparative Welfare Entitlements Data Set 2, Version 2014-03.” Available at: http://cwed2.org/.

Singer, Judith D., and John B. Willett. 2003. Applied Longitudinal Data Analysis. Modeling Change and Event Occurrence. Oxford: Oxford University Press.

Studer, Mattias. 2013. “WeightedCluster Library Manual: A Practical Guide to Creating Typologies of Trajectories in the Social Sciences with R.” LIVES Working Papers no. 24. Available online at http://dx.doi.org/10.12682/lives.2296-1658.2013.24 [March 2015].

Tuominen, Eila. 2013. "Flexible Retirement in Finland. The Evaluation of the Finnish Flexible Retirement Scheme in Light of Employer and Employee Surveys.” Finnish Centre for Pensions, Working Papers 03/2013.

Warner, David F. 2016. The Increasing Heterogeneity of Retirement in the United States: Interactions between State, Firm, and Individual Determinants of Later-Life Labor Force Withdrawal. In Delaying Retirement: Progress and Challenges of Active Ageing in Europe, The United States and Japan, edited by Dirk Hofäcker, Moritz Hess and Stephanie König, 337-62. London: Palgrave MacMillan. 
Figure 1: Expected income trajectory from midlife until old age

Income

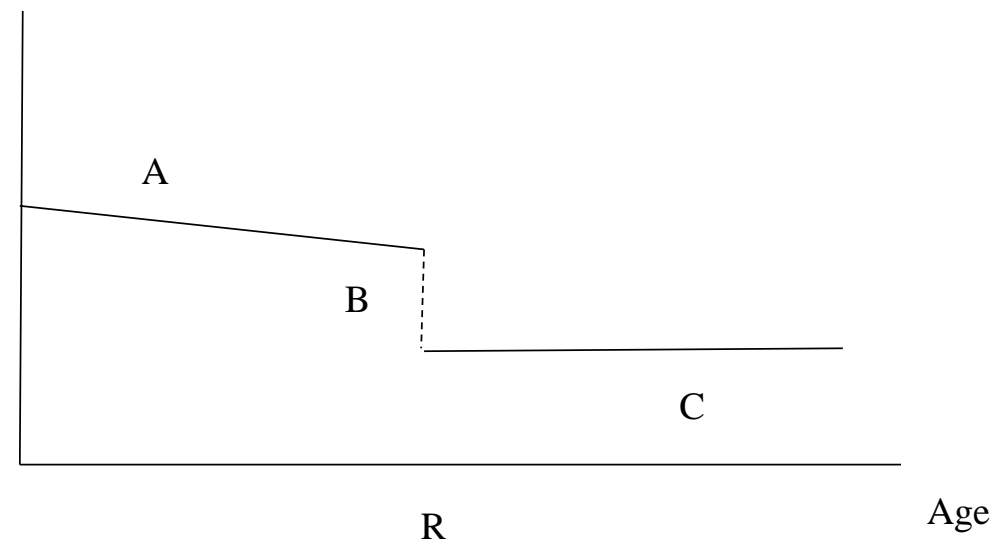

Figure 2: Composition of individual pension levels in relation to previous earnings

Pension level

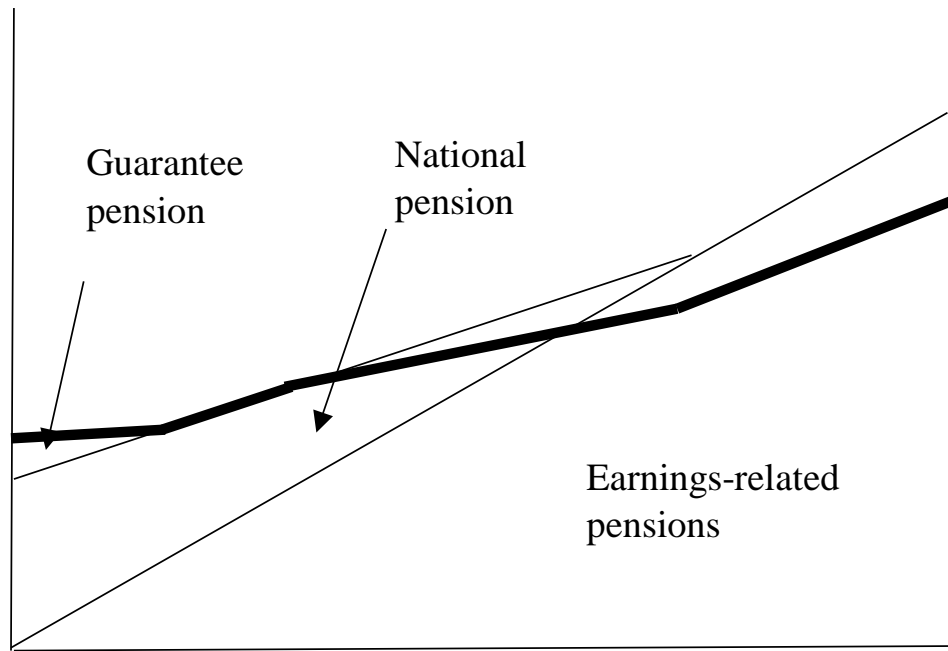

Net income

Previous earnings

Source: based on Knuuti and Ritola (2016, p. 37) 
Figure 3: Eight cluster solution following sequence analysis

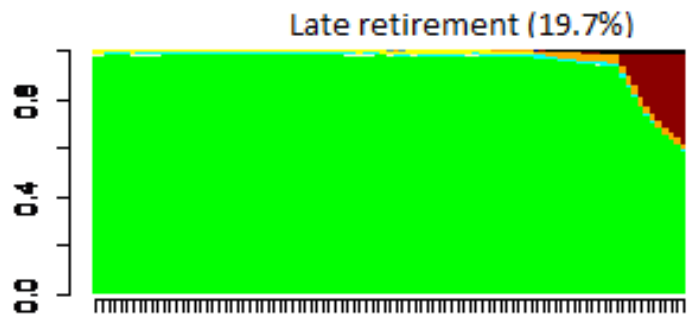

$\begin{array}{lllllllll}57 & 58 & 59 & 60 & 61 & 62 & 63 & 64 & 65\end{array}$

Death $(2.6 \%)$

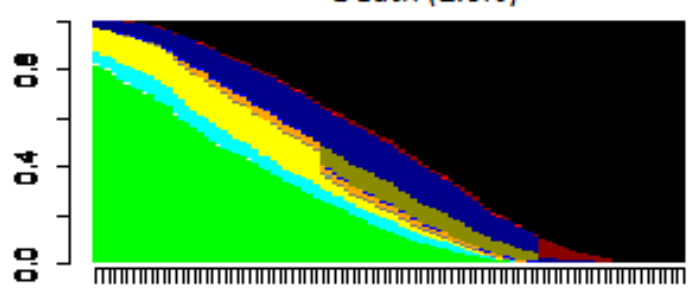

$\begin{array}{lllllllll}57 & 58 & 59 & 60 & 61 & 62 & 63 & 64 & 65\end{array}$

Early retirement $(8.3 \%)$
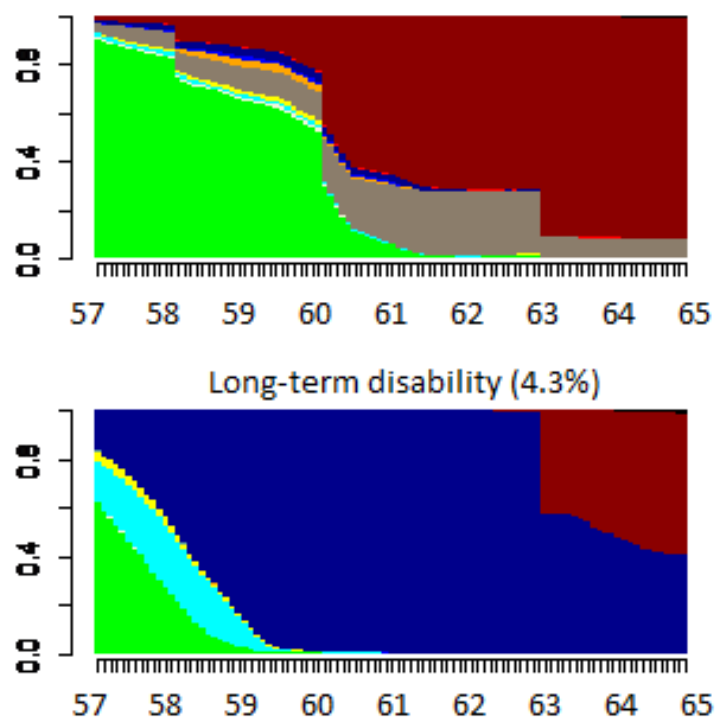

Standard retirement $(42.3 \%)$

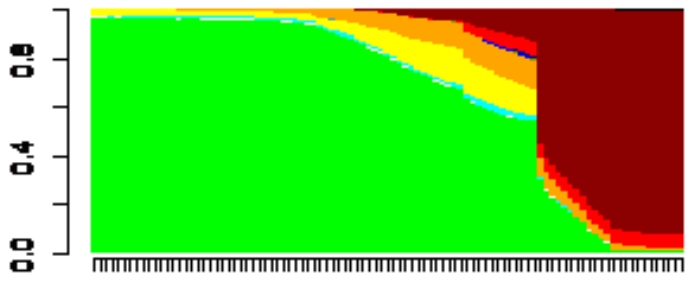

$\begin{array}{lllllllll}57 & 58 & 59 & 60 & 61 & 62 & 63 & 64 & 65\end{array}$

Disability (5.6\%)

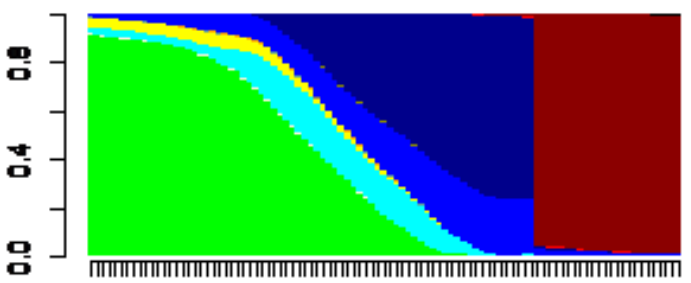

$\begin{array}{lllllllll}57 & 58 & 59 & 60 & 61 & 62 & 63 & 64 & 65\end{array}$

Part-time retirement $(6.7 \%)$

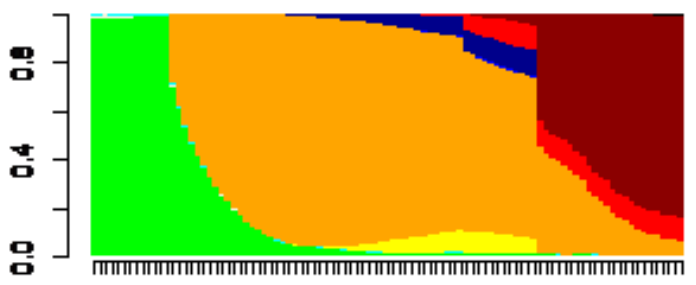

$\begin{array}{lllllllll}57 & 58 & 59 & 60 & 61 & 62 & 63 & 64 & 65\end{array}$

Unemployment (10.5\%)

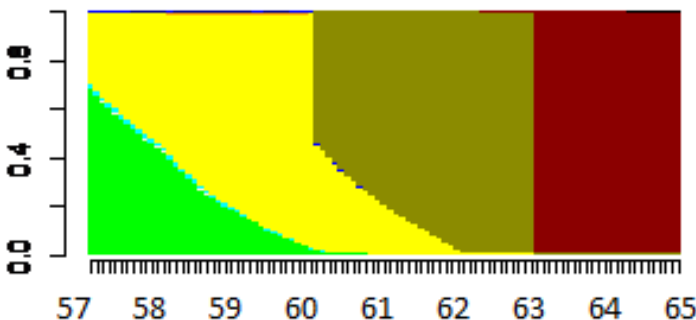

$\begin{array}{lllll}\square \text { Employed } & \square \text { Unemployment benefits } & \square \text { Part-time pension } & \square \text { Full disability pension } \\ \square \text { Other benefits } & \square \text { Other pensions } & \square \text { Partial disability pension } & \square \text { Early retirement pension } \\ \square \text { Sickness benefits } & \square \text { Rehabilitation pension } & \square \text { Unemployment pension } & \square \text { Old-age pension }\end{array}$


Figure 4: Average income from earnings, pensions and total gross and net, ages 57-66

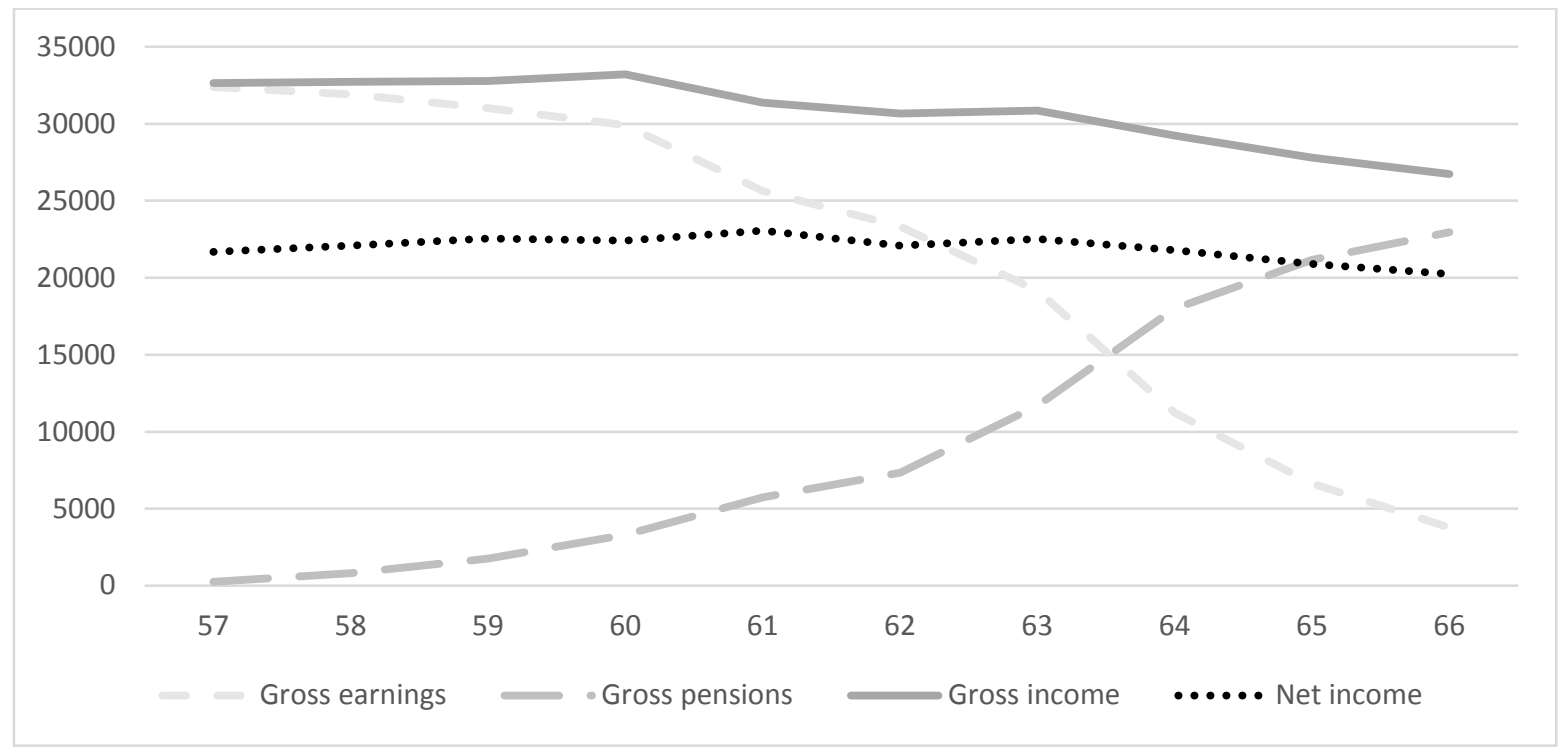


Table 1: Interpretation of the pension system's redistributive effects for various groups

\begin{tabular}{lll}
\hline Estimate for fixed effect dummy & Estimate for interaction with 'Retired' & Redistributive effect \\
\hline Positive & Positive & Cumulative advantage \\
Positive & Negative & Status levelling \\
Negative/positive & Non-significant & Status maintenance \\
Negative & Negative & Cumulative disadvantage \\
Negative & Positive & Status levelling \\
\hline
\end{tabular}

Table 2: Descriptive statistics

\begin{tabular}{llllll}
\hline Retirement pattern & Male & Female & Private sector & Public sector & $\begin{array}{l}\text { Length of } \\
\text { work history }\end{array}$ \\
\hline Standard retirement & 0.46 & 0.42 & 0.48 & 0.38 & $33.49(5.27)$ \\
Late retirement & 0.18 & 0.20 & 0.15 & 0.25 & $31.71(6.04)$ \\
Early retirement & 0.07 & 0.06 & 0.05 & 0.11 & $34.13(4.48)$ \\
Part-time retirement & 0.06 & 0.08 & 0.06 & 0.09 & $33.81(4.50)$ \\
Unemployment & 0.13 & 0.12 & 0.17 & 0.06 & $32.28(6.35)$ \\
Disability & 0.05 & 0.06 & 0.06 & 0.06 & $32.63(5.98)$ \\
Long-term disability & 0.05 & 0.04 & 0.04 & 0.05 & $32.06(6.56)$ \\
Total & 19,955 & 24,494 & 25,838 & 18,611 & $32.96(5.62)$ \\
\hline
\end{tabular}

Note: Standard deviations for the continuous work history variable shown in parentheses 
Table 3: Multilevel regression models

\begin{tabular}{|c|c|c|c|c|c|c|}
\hline & $\begin{array}{l}\text { Model 1 } \\
\text { (earnings/e-r } \\
\text { pensions) }\end{array}$ & $\begin{array}{l}\text { Model } 2 \\
\text { (gross income) }\end{array}$ & $\begin{array}{l}\text { Model 3 } \\
\text { (net income) }\end{array}$ & $\begin{array}{l}\text { Model 4 } \\
\text { (earnings/e-r } \\
\text { pensions) }\end{array}$ & $\begin{array}{l}\text { Model } 5 \\
\text { (gross } \\
\text { income) }\end{array}$ & $\begin{array}{l}\text { Model 6 } \\
\text { (net income) }\end{array}$ \\
\hline Intercept & $\begin{array}{l}10.265^{* *} \\
(0.00)\end{array}$ & $\begin{array}{l}10.264 * * \\
(0.00)\end{array}$ & $\begin{array}{l}9.890 * * \\
(0.00)\end{array}$ & $\begin{array}{l}9.597 * * \\
(0.02)\end{array}$ & $\begin{array}{l}9.595^{* *} \\
(0.02)\end{array}$ & $\begin{array}{l}9.298 * * \\
(0.01)\end{array}$ \\
\hline Year & $\begin{array}{l}0.000 \\
(0.00)\end{array}$ & $\begin{array}{l}0.001^{* *} \\
(0.00)\end{array}$ & $\begin{array}{l}0.015^{* *} \\
(0.00)\end{array}$ & $\begin{array}{l}0.002 \\
(0.00)\end{array}$ & $\begin{array}{l}0.012^{* *} \\
(0.00)\end{array}$ & $\begin{array}{l}0.030 * * \\
(0.00)\end{array}$ \\
\hline Retired & $\begin{array}{l}-0.289 * * \\
(0.00)\end{array}$ & $\begin{array}{l}-0.244^{* *} \\
(0.00)\end{array}$ & $\begin{array}{l}-0.184^{* *} \\
(0.00)\end{array}$ & $\begin{array}{l}-0.858^{* *} \\
(0.02)\end{array}$ & $\begin{array}{l}-0.332 * * \\
(0.01)\end{array}$ & $\begin{array}{l}-0.208 * * \\
(0.01)\end{array}$ \\
\hline $\begin{array}{l}\text { Years in } \\
\text { retirement } \\
\text { Work history }\end{array}$ & $\begin{array}{l}-0.001^{*} \\
(0.00)\end{array}$ & $\begin{array}{l}-0.003^{* *} \\
(0.00)\end{array}$ & $\begin{array}{l}-0.013^{* *} \\
(0.00)\end{array}$ & $\begin{array}{l}0.009 * * \\
(0.00) \\
0.025^{* *} \\
(0.00)\end{array}$ & $\begin{array}{l}0.008^{* *} \\
(0.00) \\
0.025^{* *} \\
(0.00)\end{array}$ & $\begin{array}{l}-0.007 * * \\
(0.00) \\
0.022 * * \\
(0.00)\end{array}$ \\
\hline $\begin{array}{l}\text { Year * Work } \\
\text { history }\end{array}$ & & & & $\begin{array}{l}-0.000^{* *} \\
(0.00)\end{array}$ & $\begin{array}{l}-0.000 * * \\
(0.00)\end{array}$ & $\begin{array}{l}-0.000 * * \\
(0.00)\end{array}$ \\
\hline $\begin{array}{l}\text { Retired * Work } \\
\text { history }\end{array}$ & & & & $\begin{array}{l}0.016 * * \\
(0.00)\end{array}$ & $\begin{array}{l}0.001^{* *} \\
(0.00)\end{array}$ & $\begin{array}{l}-0.000 \\
(0.00)\end{array}$ \\
\hline Female & & & & $\begin{array}{l}-0.269 * * \\
(0.01)\end{array}$ & $\begin{array}{l}-0.268^{* *} \\
(0.01)\end{array}$ & $\begin{array}{l}-0.211^{* *} \\
(0.00)\end{array}$ \\
\hline Year * Female & & & & $\begin{array}{l}-0.000 \\
(0.00)\end{array}$ & $\begin{array}{l}0.000 \\
(0.00)\end{array}$ & $\begin{array}{l}0.001^{* *} \\
(0.00)\end{array}$ \\
\hline $\begin{array}{l}\text { Retired * } \\
\text { Female }\end{array}$ & & & & $\begin{array}{l}-0.041^{* *} \\
(0.00)\end{array}$ & $\begin{array}{l}-0.023^{* *} \\
(0.00)\end{array}$ & $\begin{array}{l}-0.027 * * \\
(0.00)\end{array}$ \\
\hline Public sector & & & & $\begin{array}{l}0.037 * * \\
(0.01)\end{array}$ & $\begin{array}{l}0.039 * * \\
(0.01)\end{array}$ & $\begin{array}{l}0.032^{* *} \\
(0.00)\end{array}$ \\
\hline $\begin{array}{l}\text { Year * Public } \\
\text { sector }\end{array}$ & & & & $\begin{array}{l}-0.001 \\
(0.00)\end{array}$ & $\begin{array}{l}-0.003^{* *} \\
(0.00)\end{array}$ & $\begin{array}{l}-0.002^{* *} \\
(0.00)\end{array}$ \\
\hline Retired * & & & & $0.108 * *$ & $0.089 * *$ & $0.068 * *$ \\
\hline Public sector & & & & $(0.00)$ & $(0.00)$ & $(0.00)$ \\
\hline Late retirement & & & & $\begin{array}{l}0.057 * * \\
(0.01)\end{array}$ & $\begin{array}{l}0.058^{* *} \\
(0.01)\end{array}$ & $\begin{array}{l}0.059 * * \\
(0.01)\end{array}$ \\
\hline $\begin{array}{l}\text { Year * Late } \\
\text { retirement }\end{array}$ & & & & $\begin{array}{l}0.024^{* *} \\
(0.00)\end{array}$ & $\begin{array}{l}0.023^{* *} \\
(0.00)\end{array}$ & $\begin{array}{l}0.014^{* *} \\
(0.00)\end{array}$ \\
\hline $\begin{array}{l}\text { Retired * Late } \\
\text { retirement }\end{array}$ & & & & $\begin{array}{l}-0.082^{* *} \\
(0.01)\end{array}$ & $\begin{array}{l}-0.101^{* *} \\
(0.01)\end{array}$ & $\begin{array}{l}-0.083^{* *} \\
(0.01)\end{array}$ \\
\hline Early & & & & $0.057 * *$ & $0.060 * *$ & $0.045 * *$ \\
\hline retirement & & & & $(0.01)$ & $(0.01)$ & $(0.01)$ \\
\hline $\begin{array}{l}\text { Year * Early } \\
\text { retirement }\end{array}$ & & & & $\begin{array}{l}0.000 \\
(0.00)\end{array}$ & $\begin{array}{l}-0.000 \\
(0.00)\end{array}$ & $\begin{array}{l}0.002^{*} \\
(0.00)\end{array}$ \\
\hline $\begin{array}{l}\text { Retired * Early } \\
\text { retirement }\end{array}$ & & & & $\begin{array}{l}0.062^{* *} \\
(0.01)\end{array}$ & $\begin{array}{l}0.062^{* *} \\
(0.00)\end{array}$ & $\begin{array}{l}0.066^{* *} \\
(0.01)\end{array}$ \\
\hline Part-time & & & & 0.011 & 0.011 & $0.017^{*}$ \\
\hline retirement & & & & $(0.01)$ & $(0.01)$ & $(0.01)$ \\
\hline $\begin{array}{l}\text { Year * Part- } \\
\text { time retirement }\end{array}$ & & & & $\begin{array}{l}-0.024^{* *} \\
(0.00)\end{array}$ & $\begin{array}{l}-0.024^{* *} \\
(0.00)\end{array}$ & $\begin{array}{l}-0.016^{* *} \\
(0.00)\end{array}$ \\
\hline Retired * Part- & & & & $0.176^{* *}$ & $0.171^{* *}$ & $0.100^{* *}$ \\
\hline time retirement & & & & $(0.01)$ & $(0.01)$ & $(0.01)$ \\
\hline Unemployment & & & & $\begin{array}{l}-0.265^{* *} \\
(0.01)\end{array}$ & $\begin{array}{l}-0.258^{* *} \\
(0.01)\end{array}$ & $\begin{array}{c}-0.218^{* *} \\
(0.01)\end{array}$ \\
\hline Year * & & & & $0.005 * *$ & -0.000 & $0.005^{* *}$ \\
\hline Unemployment & & & & $(0.00)$ & $(0.00)$ & $(0.00)$ \\
\hline Retired * & & & & $-0.017^{*}$ & $0.050 * *$ & $0.052 * *$ \\
\hline Unemployment & & & & $(0.01)$ & $(0.01)$ & $(0.01)$ \\
\hline Disability & & & & $\begin{array}{l}-0.173^{* *} \\
(0.01)\end{array}$ & $\begin{array}{l}-0.167 * * \\
(0.01)\end{array}$ & $\begin{array}{l}-0.136^{* *} \\
(0.01)\end{array}$ \\
\hline $\begin{array}{l}\text { Year * } \\
\text { Disability }\end{array}$ & & & & $\begin{array}{l}-0.016^{* *} \\
(0.00)\end{array}$ & $\begin{array}{l}-0.016^{* *} \\
(0.00)\end{array}$ & $\begin{array}{l}-0.008^{* *} \\
(0.00)\end{array}$ \\
\hline
\end{tabular}


Retired *

Disability

-2 Log

Likelihood

Indicated a

\begin{tabular}{|c|c|c|c|c|c|}
\hline & & & $\begin{array}{l}0.051^{* *} \\
(0.01)\end{array}$ & $\begin{array}{l}0.097 * * \\
(0.01)\end{array}$ & $\begin{array}{l}0.079 * * \\
(0.01)\end{array}$ \\
\hline $144,297.976$ & $104,871.530$ & $-14,967.027$ & $123,795.614$ & 87,617.373 & $-30,622.811$ \\
\hline
\end{tabular}


Annex: Substitution cost matrix

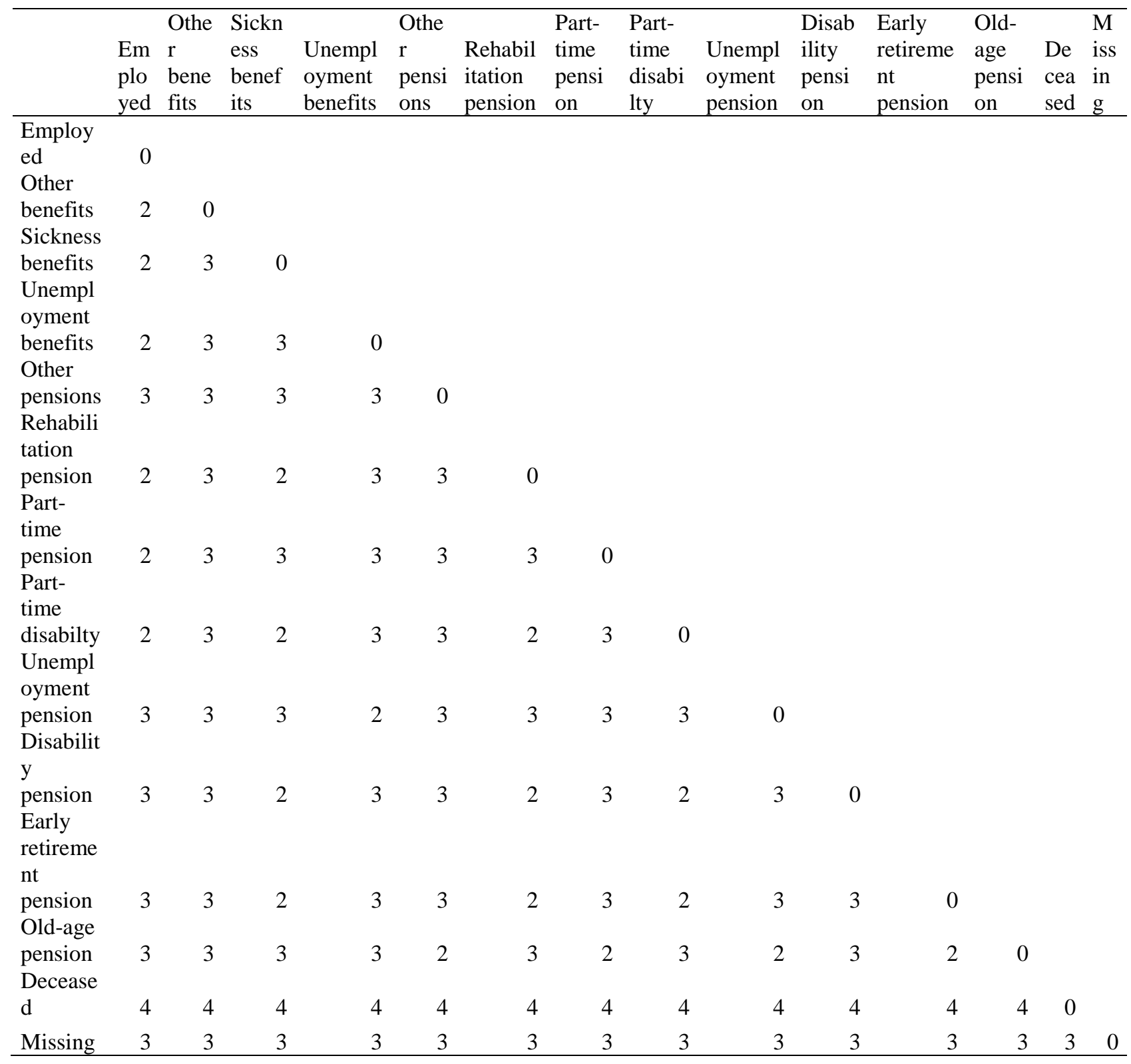

